\title{
Pendekatan Pembelajaran Matematika Realistik (PMR) Berbantuan Telegram Untuk Meningkatkan Hasil Belajar Matematika
}

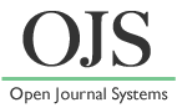

\author{
Kadek Suryati", Evi Dwi Krisna \\ STMIK STIKOM Indonesia, Denpasar, Bali 80225 \\ *Email: kadek.suryati@stiki-indonesia.ac.id \\ DOI: https://doi.org/10.33369/pendipa.5.3.479-485
}

\begin{abstract}
[Realistic Mathematic Education approach (RME) by telegram to improve mathematics' learning outcame ] The aim of this study was to determine the increase in student mathematics learning outcame after being given realistic mathematics education by telegram. The type of research was classroom action research involving subjects as many as 30 students of Technical Information (TI) class. This research was conducted in two cycles, each of which consists of planning, action, observation, evaluation, and reflection. The technique used for data analysis is descriptive statistical analysis. The result showed that the realistic mathematics education approach by telegram able to improve students mathematics learning outcames. In the pre-cycle stage the average mathematics learning outcames are 63.56 experienced an increase in the first cycle of $11.59 \%$ becomes 70.93 . Increased back of $7.71 \%$ with average 76.40 in the second cycle. For completeness learning mathematics in the pre-cycle $46.66 \%$, increased of first cycle $56.66 \%$ and second cycle increased back 70\%. Student response showed $\geq 65 \%$. So that learning with Realistic Mathematics Education (RME) by telegram can be categorized as helping student to improve their mathematics learning outcames.
\end{abstract}

Keywords: Realistic mathematics education; telegram; matehematics learning outcames.

\begin{abstract}
ABSTRAK
Tujuan dari penelitian ini adalah untuk mengetahui peningkatan hasil belajar matematika mahasiswa setelah diberikan pembelajaran matematika realistik berbantuan telegram. Penelitian ini termasuk penelitian tindakan kelas yang melibatkan subyek sebanyak 30 mahasiswa jurusan teknik informatika. Penelitian ini dilaksanakan dalam 2 siklus yang masing-masing terdiri dari perencanaan, tindakan, observasi, evaluasi dan refleksi. Teknik yang digunakan untuk analisis data adalah analisis statistik deskriptif. Hasil penelitian menunjukkan bahwa pendekatan pembelajaran matematika realistik berbantuan telegram mampu meningkatkan hasil belajar matematika mahasiswa. Ini terlihat dari rata-rata skor hasil belajar mengalami peningkatan tiap siklusnya. Pada tahap prasiklus rata-rata hasil belajar matematika yaitu 63,56 mengalami peningkatan pada siklus I sebesar 11,59\% menjadi 70,93. Meningkat kembali sebesar 7,71\% dengan rata-rata 76,40 pada siklus ke II. Untuk ketuntasan belajar matematika pada prasiklus yaitu 46,66\%, meningkat pada siklus I menjadi 56,66\% dan siklus II mengalami peningkatan kembali sebesar $70 \%$. Respon mahasiswa menunjukkan $\geq 65 \%$. Sehingga pembelajaran dengan pendekatan Pendidikan Matematika Realistik (PMR) berbantuan telegram dapat di kategorikan membantu mahasiswa untuk meningkatkan hasil belajar matematikanya.
\end{abstract}

Kata kunci: Pendidikan matematika realistik; telegram; hasil belajar matematika. 


\section{PENDAHULUAN}

Dalam dunia pendidikan pada masa sekarang ini, matematika merupakan salah satu mata pelajaran yang memiliki peranan penting dalam menunjang ilmu pengetahuan dan teknologi (IPTEK). Dengan mempelajari matematika seseorang dibiasakan untuk berpikir logis, analitis, sistematis, kritis, dan kreatif, serta memiliki kemampuan dalam memecahkan masalah baik dalam bidang matematika, bidang ilmu lainnya, maupun kehidupan sehari-hari (Indriani \& Imanuel, 2018). Matematika adalah salah satu pelajaran yang diberikan dari tingkat dasar sampai perguruan tinggi. Oleh karena itu, matematika menjadi salah satu pelajaran terpenting yang harus dikuasai oleh setiap orang. Namun, Sifat abstrak yang merupakan karakteristik dari matematika menyebabkan siswa kesulitan dalam belajar matematika.

Selain itu, belajar matematika belum bermakna, sehingga pengertian siswa tentang konsep sangat lemah. Membangun konsep matematika yang bermakna bagi peserta didik merupakan sasaran utama dalam kegiatan pembelajaran matematika. Proses belajar peserta didik hanya akan terjadi jika pengetahuan yang dipelajari bermakna bagi peserta didik. Ini akan berdampak terhadap rendahnya prestasi matematika. Menurut (Hadi, 2017) berpendapat bahwa "Data menunjukkan bahwa nilai rerata dalam ujian akhir nasional selalu di bawah 5, senada dengan kompetesi interasioal seperti IMO (International Mathematics Olympiad) siswa Indonesia menjukkan kinerja yang rendah". Dengan demikian, kemampuan pemahaman dan pemecahan masalah matematika belum optimal. Pembelajaran matematika di sekolah lebih banyak berfokus pada pencapaian target materi, sehingga konsekuesinya siswa tidak paham dengan materi. Siswa tidak membangun sendiri pengetahuan yang berkaitan dengan konsep matematika, tetapi cenderung menghafalkan rumus-rumus dan konsep pada matematika tanpa mengetahui makna sesungguhnya.

Hal ini terjadi juga pada mahasiswa perguruan tinggi di STMIK STIKOM Indonesia yang mengikuti kuliah matematika memiliki hasil belajar yang belum optimal. Tentunya tenaga pengajar terus mengupayakan untuk pembelajaran selalu efektif, namun mahasiswa sering sulit memahami materi. Dari hasil wawancara dengan dosen - dosen matematika serta melaksanakan pengamatan secara langsung. Rendahnya hasil belajar matematika mahasiswa dipengaruhi beberapa faktor yaitu Mahasiswa cenderung menghapalkan dan hanya menggunakan rumus yang diberikan sesuai dengan contoh permasalahan yang telah diberikan tanpa bisa mengembangkan, dosen juga masih berpengangan pada buku ajar dan kurang mengaitkan soal-soal atau permasalahan matematika dengan kehidupan kenyataan mahasiswa sehari-hari. Pendekatan prosedural yang masih dilakukan dalam menyampaikan materi ajar kemudian menyampaikan contoh soal yang dilanjutkan dengan kegiatan latihan mengerjakan soal. Pendekatan ini menyebabkan tenaga pengajar menjadi satu-satunya pusat informasi. Waktu ajar yang kurang dengan materi matematika yang cukup padat juga menjadi salah satu penyebab mahasiswa kurang memahami materi secara menyeluruh yang hanya berfokus pada satu sumber saja.

Menyikapi hal tersebut, pendekatan pembelajarn yang dirasa dapat memberi pengaruh terhadap hasil belajar matematika adalah pendekatan Pembelajaran Matematika Realistik (PMR) berbatuan telegram. Pendekatan Realistic Mathematics Education (RME) atau di Indonesia dikenal dengan pendekatan Pendidikan Matematika Realistik (PMR) pertama kali diperkenalkan dan dikembangkan di Belanda pada tahun 1970-an oleh sekelompok ahli matematika dari Institute Frudenthal dengan berlandaskan pada filosofi matematika sebagai aktivitas manusia (Prahmana, 2010). Pendidikan Matematika Realistik (PMR) dapat meningkatkan kemampuan pemecahan masalah pada pembelajaran matematika dan pendekatan untuk pendidikan matematika yang melibatkan siswa mengembangkan pemahaman mereka dengan mengeksplorasi dan memecahkan masalah yang ditetapkan dalam konteks yang terlibat ketertarikan siswa (Wibowo, 2017).

Kelebihan Pendidikan Matematika Realistik (PMR) antara lain yakni: Pertama yaitu PMR berpendekatan dengan bertujuan untuk membangkitkan pemahamannya sendiri akan masalah, sehingga siswa akan lebih mengingat. Kedua, pembelajaran bersifat menyenangkan peserta didik sehingga siswa lebih mudah menemukan penyelesaian permasalahan tanpa 
ada rasa takut dengan menggunakan permasalahan nyata. Ketiga, pembelajaran membuat siswa turut aktif dan terbuka terhadap pemahamannya. Keempat, proses pembelajaran dapat memupuk kerjasama dalam kelompok. Kelima, pembelajaran menemukan sendiri sehingga siswa dapat mempresentasikan hasil penyelesaiannya sendiri dan lebih mengasah keberanian. Keenam, dapat melatih siswa dalam mengemukakan pendapatnya. Ketujuh, secara tidak langsung pembelajaran dapat mendidik budi pekerti siswa. Kelebihan PMR lainnya yakni melibatkan siswa, maka pembelajaran tidak lagi menganut paradigma transfer to knowledge, sehingga berpartisipasi dalam pembelajaran (Wulandari et al., 2020).

Untuk membantu terlaksananya pendekatan Pendidikan Matematika Realistik (PMR) dengan pembelajaran di kelas yang kekurangan waktu, dan mahasiswa yang tidak bisa hadir dalam kegiatan tatap muka bisa mendapatkan materi yang telah disampaikan maka digunakanlah penambahan pada pembelajaran konvensional (tatap muka) dengan strategi online menggunakan telegram. Telegram merupakan salah satu aplikasi mobile yang mengikuti tren generasi muda sekarang yang selalu menggunakan teknologi atau smartphone untuk mendapatkan informasi, dan mengembangkan konsep matematika dengan gaya belajarnya sendiri. Aplikasi Telegram dapat diakses dan digunakan secara online dengan mudah, sehingga sesi online tidak hanya menyediakan bahan tambahan atau tugas yang terpisah tetapi untuk menambahkan hal baru, yaitu diskusi agar pembelajaran situasi tatap muka lebih berkualitas (Suryati \& Sulastra J, 2020).

Menurut Aghajani (Aghajani \& Adloo, 2018) menyatakan telegram sebagai salah satu jejaring social yang paling disukai, memiliki jutaan pengguna dari sekolah dasar hingga universitas. Di telegram, orang-orang dari segala usia dapat membuat profil mereka sendiri, mengobrol satu sama lainnya dan berbagi foto dan video favorit mereka. Ini juga memiliki aplikasi yang berguna untuk pengajaran dan pembelajaran. Ini juga merupakan alat teknologi yang dapat memelihara hubungan siswa-guru dengan menciptakan pengalaman belajar yang positif untuk kedua belah pihak. pembelajaran menggunakan telegram. Pertama oleh (Qamar \&
Riyadi, 2018) dengan penggunaan aplikasi telegram, para mahasiswa akan menghasilkan interpretasi dan ide-ide yang unik, serta menemukan cara sendiri dalam belajar. Dengan menggunakan telegram sebagai alat bantu untuk menyampaikan pengajaran, mahasiswa akan merasa seperti ada di kelas tatap muka. Di telegram mahasiswa bisa mengakses materi ajar, diskusi kelompok, dan tanya jawab tanpa harus malu karena tidak memperlihatkan diri saat bertanya. Ini semua bisa dilakukan kapan saja, dan dimana saja.

Dengan menggunakan pendekatan Pendidikan Matematika Relaistik (PMR) berbantuan telegram diharapkan bisa membantu siswa dalam memahami matematika yang bersifat abstrak dengan masalah-masalah kehidupan sehari-hari dan berbantuan telegram akan membantu mahasiswa untuk mendapatkan materi secara online. Sehingga pembelajaran menjadi lebih optimal dan dapat meningkatkan hasil belajar matematika. Berdasarkan uraian di atas, peneliti mengadakan penelitian tentang "Pendekatan Pendidikan Matematika Realistik (PMR) Berbantuan Telegram Untuk Meningkatkan Hasil Belajar Matematika".

\section{METODE PENELITIAN Waktu dan Lokasi Penelitian}

Penelitian ini dilaksanakan di kampus STMIK STIKOM Indonesia yang diadakan dari bulan Februari sampai Juni 2020.

\section{Rancangan Penelitian}

Penelitian ini merupakan pendekatan kualitatif yaitu penelitian yang ditunjukkan untuk mendeskripsikan dan memperoleh gambaran keadaan atau peristiwa secara ilmiah. Desain penelitian yang digunakan adalah penelitian tindakan kelas atau classroom action research. Sampel dari penelitian ini berjumlah 30 mahasiswa jurusan teknik informatika tahun ajaran 2020/2021. Penelitian tindakan kelas merupakan cara strategis bagi pengajar untuk memperbaiki proses pembelajaran di kelas Penelitian ini dirancang menjadi dua bagian kegiatan yaitu refleksi awal dan pelaksanaan penelitian (Sumini, 2015). Model penelitian tindakan kelas yang digunakan dalam penelitian ini adalah model Kurt Lewin yang terdiri dari empat komponen. Masing-masing komponen 
yang dimaksud yaitu (1) perencanan, (2) tindakan, (3) observasi dan evaluasi, dan (4) refleksi (Arikunto, 2008).

\section{Metode PengumpulanData}

Teknik pengumpulan data dilakukan melalui observasi, catatan lapangan, tes hasil belajar matematika yakni kemampuan menyelesaikan soal matematika dan kuisioner untuk mengetahui respon mahasiswa. Tes yang digunakan untuk mengumpulkan data hasil belajar matematika adalah tes matematika berbentuk soal uraian (essay) yang terdiri dari 5 butir soal. Tes ini dilaksanakan pada saat akhir siklus I, akhir siklus II, Sebelum digunakan, tes ini diuji validitas isi dan validitas susunannya oleh validator. Pada akhir siklus ke II disebarkan angket untuk mengetahui respon mahasiswa selama mengikuti pembelajaran dengan pendekatan yang diberikan.

\section{Teknik Analisis Data}

Teknik analisa data yang digunakan adalah metoda kuantitatif. Indikator keberhasilan dilihat dari meningkatnya rata - rata pada setiap siklusnya dan respon mahasiswa menggunakan angket skala guttman (Arikunto, 2008) yaitu skala yang digunakan untuk memperoleh jawaban yang jelas dan bersifat tegas dan konsisten, pada penelitian ini digunakan jawaban "ya" dan "tidak" untuk mencari tahu bagaimana faktor-faktor yang mempengaruhi hasil belajar mahasiswa.

\section{HASIL DAN PEMBAHASAN}

Berdasarkan hasil penelitian menggunakan pendekatan pendidikan matematika realistik berbantuan telegram yang dilaksanakan dengan 2 siklus dapat dirangkum pada tabel 1 yang menggambarkan tentang peningkatan rata-rata hasil belajar matematika, ketuntasan belajar serta daya serap mahasiswa dari pra-siklus, siklus I dan siklus II. Untuk mempermudah melihat peningkatan tersebut dapat dilihat gambar 1, gambar 2 serta gambar 3. Hasil ini diperoleh setelah mahasiswa mengerjakan tes akhir setiap berakhirnya siklus. Terlihat dari pra-siklus sampai dengan siklus ke 2 mengalami peningkatan hasil belajar mahasiswa yang dilihat dari nilai rata-rata tes matematika yang diberikan.
Tabel 1. Hasil Belajar Matematika Mahasiswa

\begin{tabular}{|c|c|c|c|c|c|c|c|}
\hline \multirow{2}{*}{$\begin{array}{l}1 \\
0\end{array}$} & \multirow{2}{*}{$\begin{array}{l}\text { Katego } \\
\text { ri }\end{array}$} & \multicolumn{2}{|c|}{ Pra-Siklus } & \multicolumn{2}{|c|}{ Siklus I } & \multicolumn{2}{|c|}{ Siklus II } \\
\hline & & $\mathrm{F}$ & $\mathrm{P}$ & $\mathrm{F}$ & $\mathrm{P}$ & $\mathrm{F}$ & $\mathrm{P}$ \\
\hline 1 & $\begin{array}{l}\text { Belum } \\
\text { Tuntas }\end{array}$ & $\begin{array}{l}1 \\
6\end{array}$ & $\begin{array}{l}53,34 \\
\%\end{array}$ & $\begin{array}{l}1 \\
3\end{array}$ & $\begin{array}{l}43,34 \\
\%\end{array}$ & 9 & $30 \%$ \\
\hline 2 & Tuntas & $\begin{array}{l}1 \\
4 \\
\end{array}$ & $\begin{array}{l}46,66 \\
\%\end{array}$ & $\begin{array}{l}1 \\
7\end{array}$ & $\begin{array}{l}56,66 \\
\%\end{array}$ & $\begin{array}{l}2 \\
1 \\
\end{array}$ & $70 \%$ \\
\hline \multicolumn{2}{|c|}{ Jumlah } & $\begin{array}{l}3 \\
0\end{array}$ & $100 \%$ & $\begin{array}{l}3 \\
0\end{array}$ & $100 \%$ & $\begin{array}{l}3 \\
0\end{array}$ & $\begin{array}{l}100 \\
\%\end{array}$ \\
\hline \multicolumn{2}{|c|}{$\begin{array}{l}\text { Rata-rata } \\
\text { Skor }\end{array}$} & \multicolumn{2}{|c|}{63,56} & \multicolumn{2}{|c|}{70,93} & \multicolumn{2}{|c|}{76,40} \\
\hline \multicolumn{2}{|c|}{ Daya Serap } & \multicolumn{2}{|c|}{$63,56 \%$} & \multicolumn{2}{|c|}{$70,93 \%$} & \multicolumn{2}{|c|}{$76,40 \%$} \\
\hline
\end{tabular}

\section{Rata-rata Skor Hasil belajar Mahasiswa}

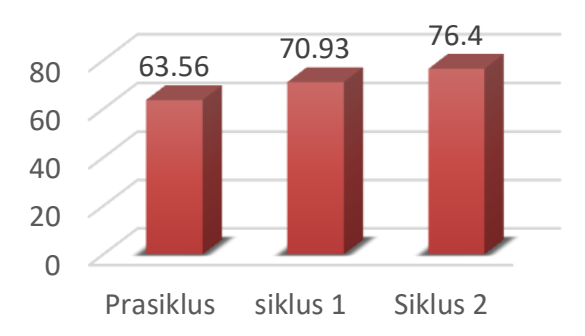

Gambar 1. Peningkatan Rata-Rata Skor Tes Hasil Belajar Matematika

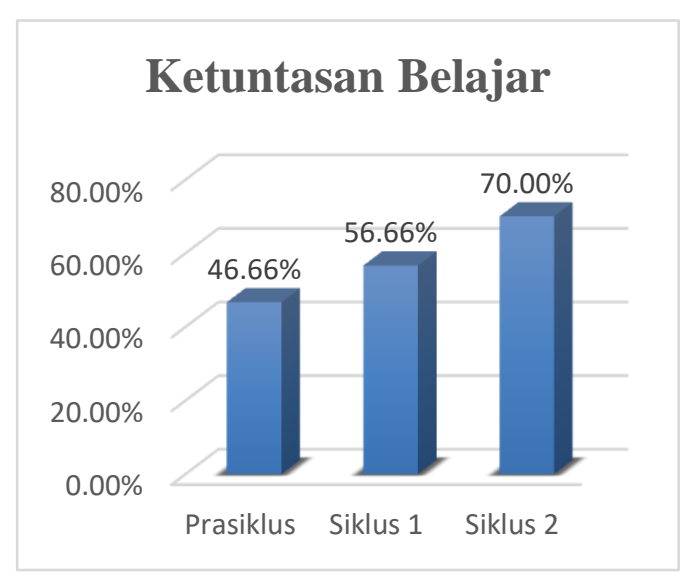

Gambar 2. Peningkatan Ketuntasan Belajar Matematika Mahasiswa 


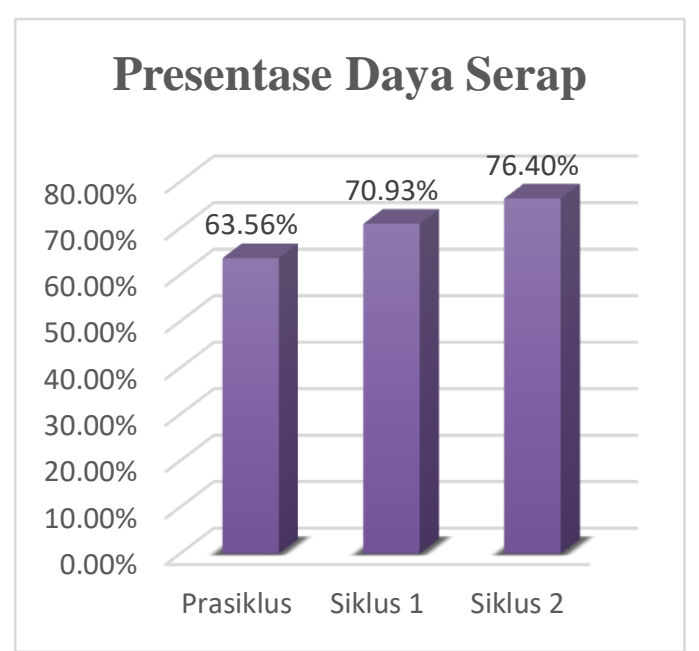

Gambar 3. Peningkatan Daya Serap Matematika Mahasiswa

Dari tabel 1 dan gambar 1, 2, 3 di atas dapat dilihat bahwa dari pra-siklus, siklus I dan siklus II terjadi peningkatan terhadap nilai matematika mahasiswa yang mengikuti pembelajaran Pendidikan Matematika Realistik (PMR) berbantuan Telegram. Pada masa pra-siklus di peroleh hasil matematika yang belum optimal ini dapat dilihat dari banyaknya mahasiswa yang belum mencapai nilai ketuntasan 70 sebesar $53,34 \%$ sekitar 16 orang dan 46,66\% sekitar 14 orang yang sudah mencapai nilai tuntas. Dengan nilai rata-rata nilai yaitu 63,56 daya serap sebesar $63,56 \%$. Hal ini menunjukkan nilai hasil belajar mahasiswa masih tergolong rendah. Berdasarkan hal tersebut peneliti melaksanakan penelitian tindakan kelas dengan menerapkan pendekatan pembelajaran Pendidikan Matematika Realistik (PMR) berbantuan Telegram.

Pada masa siklus I hasil penelitian menunjukkan adanya peningkatan hasil belajar matematika mahasiswa dengan persentase ketuntasan belajar sebesar 56,66 \% yang mencapai indikator keberhasil belajar nilai tuntas 70 sekitar 17 orang dan belum mencapai ketuntasan sebesar 13 orang atau 43,34\%. Dengan rata-rata nilai $70,93 \%$ dan daya serap sebesar 70,93\%. Hal ini menunjukkan nilai hasil belajar matematika mahasiswa tergolong baik. Secara umum pembelajaran dengan pendekatan matematika realistik berlangsung cukup baik pada siklus I. namun demikian ada beberapa kendala yang masih dihadapi mahasiswa yang dapat dijadikan pertimbangan atau refleksi untuk perbaikan siklus berikutnya. Adapun masalah yang dihadapi yaitu waktu yang kurang pada saat pembelajaran dikelas menyebabkan diskusi dan latihan soal belum terbahas dan mahasiswa masih belum terbiasa menggunakan telegram dalam melaksanakan diskusi atau tanya jawab, mahasiswa masih beranggapan bahwa ketika mengemukan pendapatnya akan diberi tanggapan kurang mampu / tidak bisa dalam materi yang diajarkan, mahasiswa masih belum terbiasa diberikan contoh realistik di dalam menyelesaikan masalah sehingga ragu-ragu untuk mengerjakan latihan soal yang diberikan, ada beberapa mahasiswa yang tidak begitu aktif dalam kelas online telegram, karena mengangap membuang-buang waktu. hal ini menyebabkan kuranganya peningkatan aktivitas mahasiswa saat belajar, Hal ini sesuai dengan pendapat Treffers (dalam wijaya, 2012) mengenai karakteristik interaksi pembelajaran akan lebih bermakna ketika mahasiswa saling mengkomunikasikan hasil kerja dan gagasannya.

Dengan beberapa kendala tersebut maka peneliti melakukan evaluasi pada siklus ke II sehingga pembelajran menjadi lebih optimal. Untuk mengatasi permasalahan yang ditemui pada siklus I, dilakukan beberapa strategi dan tindakan perbaikan. Pertama, adalah mahasiswa diberi penjelasan kembali mengenai pembelajaran dengan pendekatan Pendidikan Matematika Realistik (PMR) yang sedang diterapkan. Hal ini dilakukan agar mahasiswa lebih paham dengan prosedur pembelajaran yang akan membiasakan mahasiswa untuk membangkitkan pemahamannya sendiri akan masalah, sehingga siswa akan lebih mengingat, mahasiswa lebih sering diajak merekontruksi pengetahuannya sendiri dengan masalah-masalah nyata atau benda-benda kongkrit yang ada di sekitar lingkungan. Hal ini akan menjadikan pembelajaran lebih bermakna bagi mahasiswa. Hal tersebut sesuai dengan pendapat (Liwis et al., 2017), pembelajaran matematikaxrealistik bahwa pembelajaran menekankan kebermaknaan yang mengaitkan aktivitas yang berkaitan dengan kehidupan nyata dan dekat dengan lingkungan anak dalam suatu pembelajaran dapat diperoleh melalui berbagai cara.

Selain itu pada siklus kedua peneliti menerapkan prinsip structuring and interwining di mana peneliti mengaitkan pembelajaran pada 
siklus kedua dengan pembelajaran siklus pertama karena ketika mahasiswa langsung diberikan materi, tanpa melakukan pengaitan dengan pengetahuan yang telah mahasiswa miliki maka materi yang dipelajari mahasiswa menjadi tidak bermakna atau abstrak. Mahasiswa tidak akan paham maksud dari materi yang diajarkan. Untuk penggunaan telegram, peneliti memberikan penjelasan ulang, bahwa penggunaan telegram bisa membantu mahasiswa dalam mencari materi yang dijelaskan pada saat tatap muka, mahasiswa juga dijinkan untuk bebas bertanya tanpa menyebutkan identitas sehingga mahasiswa tidak lagi malu bertanya atau memberikan tanggapannya, mahasiswa juga diberikan reward saat mengikuti kuis pada saat diskusi online sehingga pembelajaran menjadi lebih menarik dan mahasiswa aktif mengikuti pembelajaran yang telah diterapkan.

Setelah melaksanakan evaluasi maka diperoleh hasil belajar matematika mahasiswa pada siklus ke II lebih optimal. Ini terlihat dari nilai ketutasan mahasiswa sebesar $70 \%$ naik dari siklus I sebesar $13,34 \%$. Ini menyatakan bahwa sekitar 21 orang mencapai kriteria nilai tuntas. Rata-rata hasil belajar mahasiswa 76,40 dengan daya serap belajar $76,40 \%$. Rata-rata nilai tes matematika, ketuntasan belajar, dan daya serap sudah mencapai kriteria pembelajaran minimal yang telah ditetapkan yaitu rata-rata nilai tes matematika $(\mathrm{M}) \geq 70$, ketuntasan belajar $(\mathrm{KB}) \geq$ $75,00 \%$ dan daya serap (DS) $\geq 65,00 \%$. Dengan berakhirnya siklus ke II, maka peneliti ingin mengetahuti respon mahasiswa terhadap pendekatan yang diberikan. Dari hasil analisis respon mahasiswa diperoleh persentase setiap aspek pertanyaan berada di $\geq 65 \%$. Sehingga pembelajaran dengan pendekatan Pendidikan Matematika Realistik (PMR) berbantuan telegram dapat di kategorikan membantu mahasiswa untuk meningkatkan hasil belajar matematikanya.

\section{KESIMPULAN}

Berdasarkan hasil penelitian yang telah dilakukan, maka dapat disimpulkan beberapa hal sebagai berikut:

1. Terjadi peningkatan hasil belajar matematika pada mahasiswa jurusan teknik informatika yang melaksanakan pembelajaran dengan pendekatan
Pendidikan Matematika Realistik (PMR) berbantuan telegram. Hal ini terlihat dari pra-siklus sampai dengan siklus ke II diperoleh rata-rata nilai hasil belajar matematika naik sebesar 7,37 \% pada siklus I dengan ketuntasan belajar mahasiswa sebanyak 17 orang mencapai nilai kriteria tuntas dengan daya serap sebesar $70,93 \%$. Pada siklus ke II ketuntasan belajar mahasiswa sebesar $70 \%$ dengan 9 orang yang belum mencapai ketuntasan. Untuk penilaian hasil belajar matematika mahasiswa meningkat sebesar $13,34 \%$ dari siklus I dengan rata-rata 76,40 dengan kategori baik.

2. Respon mahasiswa terhadap pembelajaran dengan pendekatan dengan Pendidikan Matematika Realistik (PMR) berbantuan telegram diperoleh persentase setiap aspek pertanyaan berada di $\geq 65 \%$. Hal ini dapat di kategorikan membantu mahasiswa untuk meningkatkan hasil belajar matematikanya.

\section{DAFTAR PUSTAKA}

Aghajani, M., \& Adloo, M. (2018). The effect of online cooperative learning on students' writing skills and attitudes through telegram application. International Journal of Instruction.

https://doi.org/10.12973/iji.2018.11330a

Arikunto, Suharsimi. 2008. Penelitian Tindakan Kelas. Jakarta: Bumi Aksara

Hadi, S. (2017). Pendidikan Matematika Realistik: Teori, Pengembangan, dan Implementasinya. Jakarta: Rajawali Pers.

Indriani, M. N., \& Imanuel, I. (2018). Pembelajaran Matematika Realistik Dalam Permainan Edukasi Berbasis Keunggulan Lokal Untuk Membangun Komunikasi Matematis. Prosiding Seminar Nasional Matematika.

Liwis, N., Aditya Antara, P., \& Rahayu Ujianti, P. (2017). Pengaruh Model Pembelajaran Matematika Realistik Terhadap Kemampuan Mengenal Konsep Bilangan 
Pada Anak Kelompok a Taman KanakKanak Gugus V Kecamatan Buleleng. EJournal Pendidikan Anak Usia Dini Universitas Pendidikan Ganesha.

Prahmana, R. C. I. (2010). Permainan “Tepuk Bergilir" Yang Berorientasi Konstruktivisme Dlam Pembelajaran Konsep KPK Siswa Kelas IV A Di SD N 21 Palembang. Jurnal Pendidikan Matematika.

Qamar, K., \& Riyadi, S. (2018). Efektivitas Blended Learning Menggunakan Aplikasi Telegram. At-Tajdid : Jurnal Ilmu Tarbiyah.

Sumini. 2015. Penelitian Tindakan Kelas dan dasar-dasar Profesi guru. Universitas Sanata Dharma, Yogyakarta.

Suryati \& Sulastra J (2020). Interaksi Strategi Blended Learning Berbantuan Telegram Terhadap Hasil Belajar Matematika Siswa yang Ditinjau dari Gaya Belajar. Jurnal Kajian, Penelitian Dan Pengembangan Kependidikan
Wibowo, A. (2017). Pengaruh pendekatan pembelajaran matematika realistik dan saintifik terhadap prestasi belajar, kemampuan penalaran matematis dan minat belajar. Jurnal Riset Pendidikan Matematika. https://doi.org/10.21831/jrpm.v4i1.10066

Wijaya, A. (2012). Pendidikan Matematika Realistik; Suatu Alternatif Pendekatan Pembelajaran Matematika. Yogyakarta: Graha Ilmu

Wulandari, N. P. R., Dantes, N., \& Antara, P. A. (2020). Pendekatan Pendidikan Matematika Realistik Berbasis Open Ended Terhadap Kemampuan Pemecahan Masalah Matematika Siswa. Jurnal Ilmiah Sekolah Dasar.

https://doi.org/10.23887/jisd.v4i2.25103 